\title{
Implementation of Universal Design in South Asian Countries
}

\author{
Nisha Prajapati \\ Nagaoka University of Technology \\ E-Mail: nisha.prajapati@gmail.com \\ Tatsuo Asai \\ Nagaoka University of Technology \\ E-Mail: asaitats@gmail.com
}

\begin{abstract}
As the aged and the disabled show a desire and a determination to live productive lives, universal design (UD) products could allow independence in daily life among these people. UD products are designed in such a way that they are usable to the greatest extent possible, by people of all ages and abilities. This research uses a descriptive analysis of data collected through a survey of 142 respondents in South Asian countries to determine their levels of awareness and practice of UD, willingness to pay more for UD products and preferred features in durable goods. The survey results show that South Asians are not very aware of UD, even though UD is already being incorporated into durable goods. There are three reasons driving market opportunities for UD products in South Asia. First is the consumers' belief that the market for durable goods will increase. Second is the consumers' willingness to pay 25\% higher for UD products. Finally, consumers face problems while using products even though they have no disability. Furthermore, this paper discusses why some consumers like or do not like features in current products. This paper also discusses easier and safer features preferred by consumers of all age groups.
\end{abstract}

Keywords: Awareness, Durable Goods, Practice, South Asia, Universal Design

\section{INTRODUCTION}

Universal Design (UD) is the design of products and environments to be usable by all people, to the greatest extent possible, without the need for adaptation or specialized design (Mace, 1988). Initially, UD was incorporated into the built 
environment and information technology. It is, however, being incorporated in a variety of fields now.

There are several studies concerning the importance of UD in ergonomics, human-centered technology and information technology. Well-known approaches like “User’s Pyramid” (Benktzon, 1993), “The Inclusive Design Cube” (Keates, Clarkson, Harrison, \& Robinson, 2000), and "Bottoms Up" (Goldsmith, 2001) are some examples, which are incorporated in the products or services and built environment (buildings, streets and communication etc). Furthermore, some researchers discuss a trend towards UD to increase overall performance of a company (Steinfeld \& Shea, 2001; Asai \& Konta, 2006; Hasegawa \& Asai, 2007).

Other researchers discuss trends of UD in different countries (Singanpalli, 2001; Ikeda, 2005; Erlandson, 2008). UD has been drawing attention in many parts of the world. Despite rapid demographic change, economic growth and development growth in many developing countries are similar to those of developed countries. UD is, however, limited to the developed countries. It is natural to view UD in South Asia in a different perspective than UD in developed countries.

Prajapati and Asai (2009) have studied UD in the context of India to know its practices. They state that India has adopted UD in infrastructure and education. The authors assumed that the present condition of UD in other South Asian countries is similar to that in India. In this paper, the authors have expanded their research to other South Asian countries.

South Asia is home to well over one fifth of the world's population, making it the most populous geographical region in the world. In addition, South Asia is home to more than a quarter of the world's disabled population. South Asia is a group of eight countries. These countries have many similarities in demographic, social, economic, geographic, and political aspects (Agarwal \& Anand, 2007). In this paper, South Asia is limited to Bangladesh, India, Nepal, and Sri Lanka and the rest of the South Asian countries are included as others (Afghanistan, Bhutan, Maldives and Pakistan). The reason for combining a group of countries as "others" is because a low number of respondents to our survey came from those countries.

The main motivation behind this research is a current scenario of problems in South Asia. This scenario consists of rapid aging (see Figure 1), a trend of increase in nuclear families (couple), increase in the number of women jobholders, increase in disposable income and increase in production of multi-functional products etc. The aged and the disabled have expressed a desire and a determination to live productive lives and also to make their own individual contributions to society. 


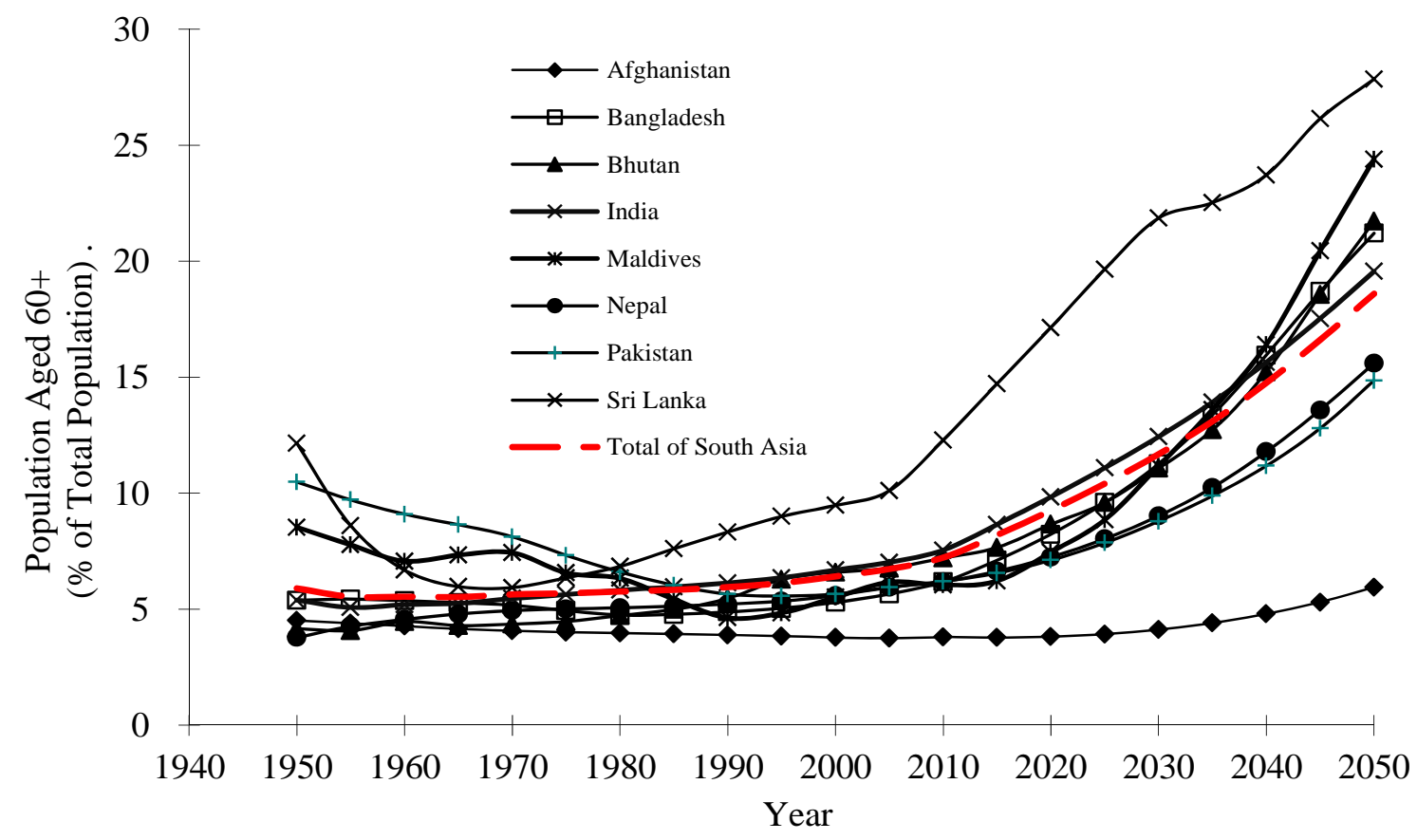

Figure 1 Trends of Aged 60+ in South Asia

Source: UN DESA (2008)

The main purposes of this research are

- to learn the current level of awareness of UD and level of practices of UD.

- to identify the problems faced by consumers while consuming ordinary products.

- to identify the potential market for UD.

- to assess consumers' willingness to pay for UD products.

- to provide recommendations to producers, designers, and decision makers.

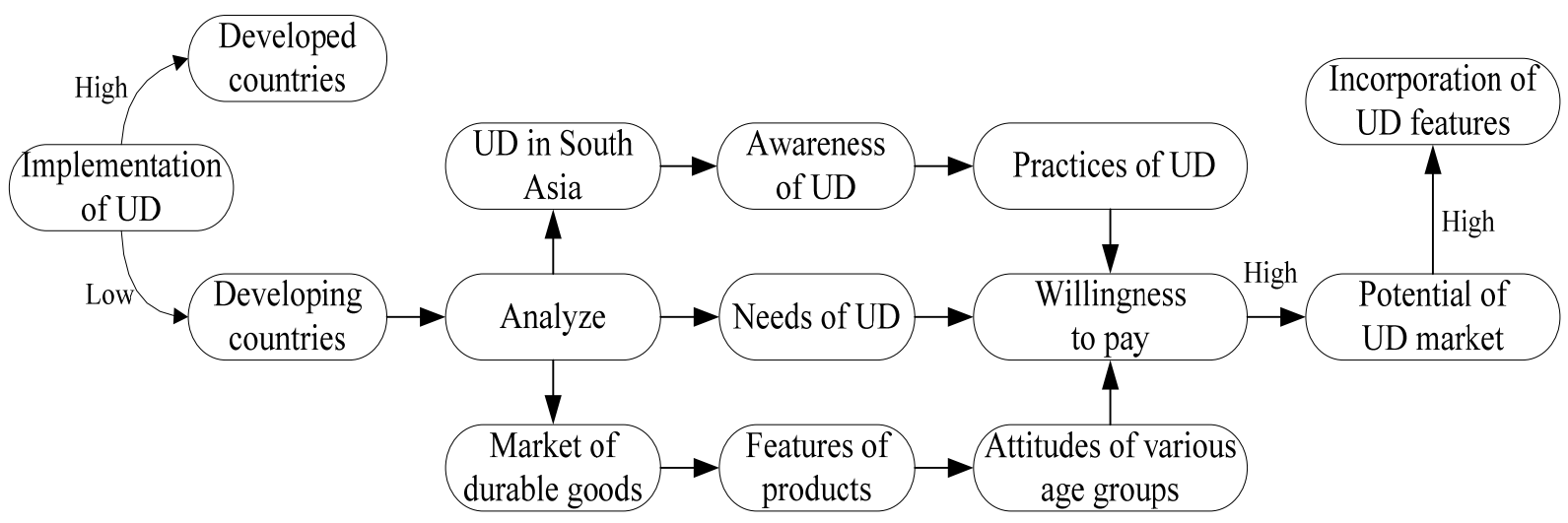

Figure 2 Research Framework 
A research framework (Figure 2) has been developed to attain these purposes. The framework depicts that there is a gap of implementation of UD between developed countries and developing countries. Thus, this research analyzed UD in South Asia, needs of UD, present market of durable goods, willingness to pay for UD products and business opportunities of UD in South Asia. The results will motivate producers and designers to incorporate UD features.

\section{BACKGROUNDS AND DEVELOPMENT OF HYPOTHESES}

The environments of developing countries are different from those of developed countries. Similarly, those who live in developing countries have a different level of awareness and different expectations about products are also different from developed countries. Producers and designers are tasked with the challenge of making the right strategic choices and strategic priorities to make the right design of a product. Ashok and Jacko (2009) state that whenever residents in the Western world visit countries in Asia, many of them are surprised by Asians' eating habits and modes of transportation, which are radically different from theirs. This view is consistent with Singanpalli's (2001) view that in traditional countries like India, people do not readily accept new products. There are strong taboos against new products associated with certain semantic notions (e.g. an antipollution mask, which resembles a pig face), colors and forms.

Similarly, Wijk (2001) mentions that there are only two types of design: bad design and good design. Bad design is always a result of ignorance or failures, whereas good design is free of failures, as designers use the knowledge available about human needs and differences. It implies that designers should have knowledge about human needs. Furthermore, Pauls (2001) says that fatal and nonfatal injuries should be prevented through product design because many nonfatal injuries result in permanent disabilities and reduction of quality of life.

Nowadays, the concept of UD is emerging slowly in South Asian countries, mainly in India. Singanapalli (2001) says that it is better to incorporate UD throughout India, as its benefits in developed countries are evident. According to Raheja (2007), the Indian government has passed legislation aimed at achieving equality of opportunity and full participation for the disabled. Prajapati and Asai (2010) state that UD features should be incorporated according to preference of South Asians. Furthermore, Prajapati and Asai (2010) proposed new approach "Start with small changes" in products features to adopt UD. In addition, Yoshida and Asai (2009) state 
that there is a strong positive correlation between the company's level of commitment to UD and its corporate values.

The previous literature provides little direction regarding the influences that encourage consumers to adopt UD features. Using previous literature as guidance, the authors have created some hypothesized questions. This research focuses on a survey conducted in South Asian countries. The questionnaire is targeted at consumers of durable goods rather than producers and designers because of the following reasons:

- there are very few companies outside of India that produce durable goods in South Asia;

- this research tries to cover a large number of respondents;

- it is easy to motivate a few people to utilize UD rather than the entire population.

The following hypotheses have been developed to respond to the research question:

- South Asian people are less familiar with UD.

- There is an association between the awareness of UD and gender.

- There is an association between the awareness of UD and the belief that UD is in practice.

- There is an association between the awareness of UD and the belief that UD will increase the market of UD products.

- Some durable goods are not acceptable in all countries.

- There is an association between the country of residence and people's willingness to pay for UD products.

This paper studies the association between questions and the characteristics of respondents and the association between two questions by using the Chi square $\left(\chi^{2}\right)$ test of independence. A confidence level of 95\% was used, and assumption of normality was checked for both tests. The data is analyzed by using SPSS. Furthermore, multiple response frequencies were calculated and pie charts were made to show their coverage percentages. In addition, cross tabulations were carried out between multiple response questions and others by converting the responses into 100 percent. 
Table 1 Characteristics of Respondents (2009) $\quad(n=142)$

\begin{tabular}{|c|c|c|c|}
\hline \multicolumn{2}{|c|}{ Characteristics } & \multirow{2}{*}{$\begin{array}{c}\text { Frequency } \\
131\end{array}$} & \multirow{2}{*}{$\begin{array}{c}\text { Proportion (\%) } \\
92\end{array}$} \\
\hline$A$ & Urban & & \\
\hline माга & Rural & 11 & 8 \\
\hline \multirow{3}{*}{ Age } & $20-39$ & 91 & 64 \\
\hline & $40-59$ & 37 & 26 \\
\hline & 60 or over & 14 & 10 \\
\hline \multirow{5}{*}{ Country } & Bangladesh & 24 & 17 \\
\hline & India & 25 & 17 \\
\hline & Nepal & 54 & 38 \\
\hline & Sri Lanka & 21 & 15 \\
\hline & Others & 18 & 13 \\
\hline \multirow{2}{*}{ Gender } & Male & 103 & 73 \\
\hline & Female & 39 & 27 \\
\hline \multirow{5}{*}{ Household } & A single person/A single parent & 18 & 13 \\
\hline & A couple with no child & 19 & 13 \\
\hline & A couple with children & 67 & 47 \\
\hline & Have family members with disabilities & 5 & 4 \\
\hline & Joint family & 33 & 23 \\
\hline \multirow{4}{*}{ Education } & Illiterate & 0 & 0 \\
\hline & Higher Secondary level & 2 & 1 \\
\hline & Bachelors Degree & 34 & 24 \\
\hline & Master's Degree or higher & 106 & 75 \\
\hline \multirow{4}{*}{ Occupation } & Services & 101 & 71 \\
\hline & Agriculture & 6 & 4 \\
\hline & Industry & 0 & 0 \\
\hline & Others & 35 & 25 \\
\hline
\end{tabular}

\section{OPINION SURVEY}

The study was carried out through a survey approach. This survey was conducted between March 2009 and December 2009 via direct personal contact and email. A self-administered questionnaire with multiple-choice questions was used. The questionnaires for different countries basically featured the same question and answer option, so that the results of survey could be compared. The options for answers, however, in several questions were adjusted to reflect the circumstances of each 
country, and some additional questions were included in the questionnaire. The questionnaire has two sections. The first section has questions which gauge a number of issues related to attempts to purchase durable goods. A literature study was conducted to identify various influencing attributes. A draft questionnaire was made and tested on 30 residents of South Asian countries. This exercise ensured the adequacy and communicability of the questions in the questionnaire.

The language used is English. Adequate measures were taken to make sure that the respondents did not misunderstand the questions. Based on the feedback obtained from these respondents, the final version of the questionnaire was developed. In the second section, some questions related to personal information were asked.

The number of valid respondents is 142. The survey focuses on those countries whose responses are more than 20. Table 1 shows the characteristics of respondents in both frequency and percentage. The majority of respondents are from Nepal, whereas Sri Lanka constitutes the lowest number of respondents. The table shows that the age group between 20 and 30 is the largest (64\%). Furthermore, there are no illiterate respondents and there are no respondents from the industry sector.

\section{EXPLORATION OF ACTUAL SITUATION IN SOUTH ASIA}

\section{UD in South Asia}

\section{- Level of Awareness of UD}

The survey results in Figure 3 show that the most familiar UD-related terminology among South Asians was “design for all.” It was known by $26 \%$ of the respondents and was 4\% higher than the percentage of respondents who knew the term UD. In contrast, the least-familiar terminology was "ageless design." The unfamiliar respondents occupied $62 \%$ of the respondents, which was $27 \%$ (62\%-35\%) more than the percentage of respondents who were unfamiliar with UD. Twenty-two percent of respondents were familiar with UD, followed by $44 \%$ of respondents who were a bit familiar with UD, and 35\% who were not familiar with UD. It implies that “design for all” is the most familiar term among South Asians. They are, however, not so familiar with UD and similar terminologies. UD is expressed using various terms across the world. The British use "design for all”, Americans use "inclusive design" and Japanese use "universal design” (Elokla, Morita, \& Hirai, 2006). South Asians are more familiar with "design for all," which implies that they are influenced more by the British culture than that of the Americans or the Japanese in the business world. It 
revealed that South Asians are incorporating UD in the term of "design for all" in products. To allow more people to live productive lives, however, awareness of UD in South Asia should be enhanced in South Asia.

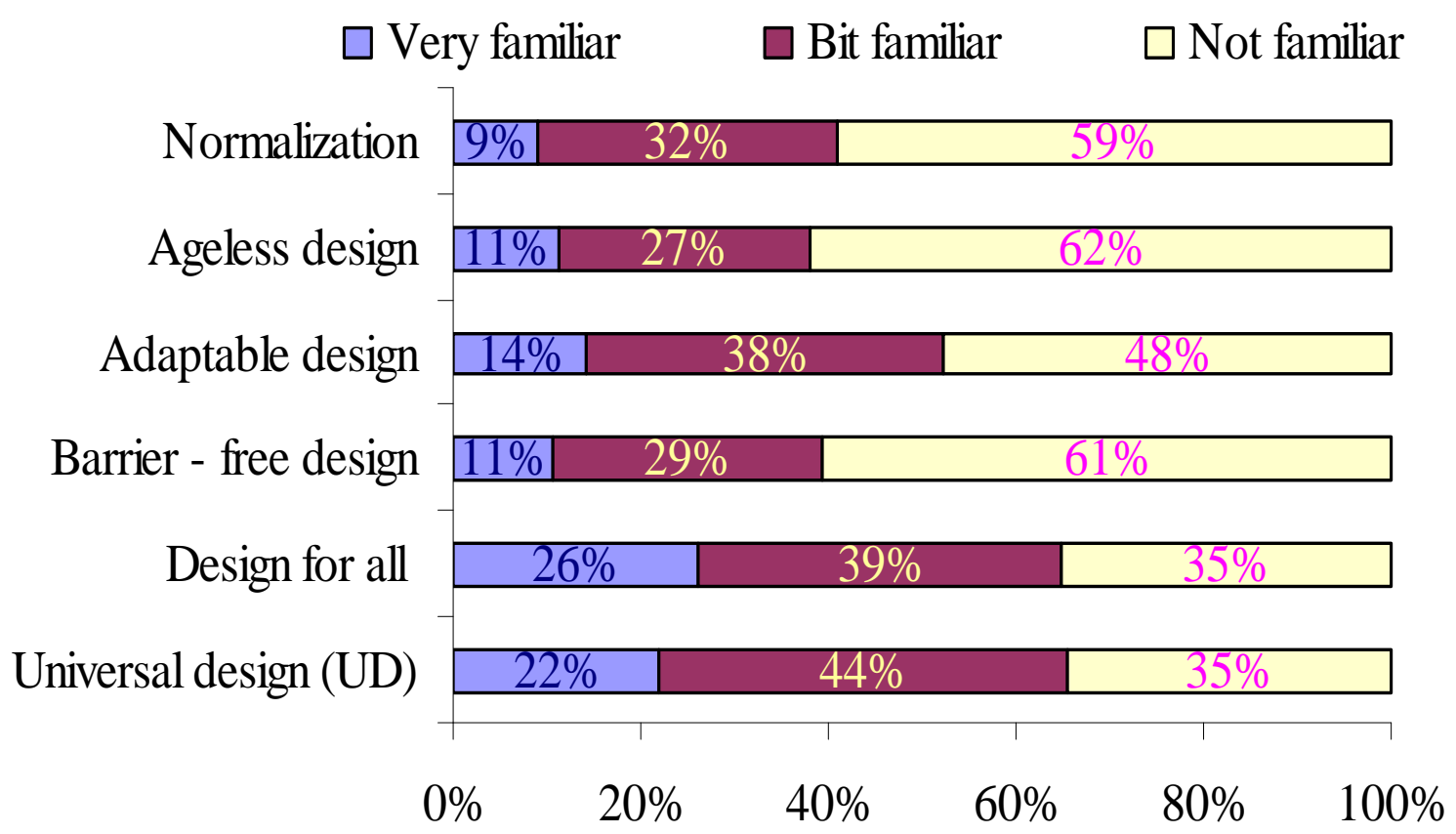

Figure 3 Awareness of the Design Terminologies $(n=142)$

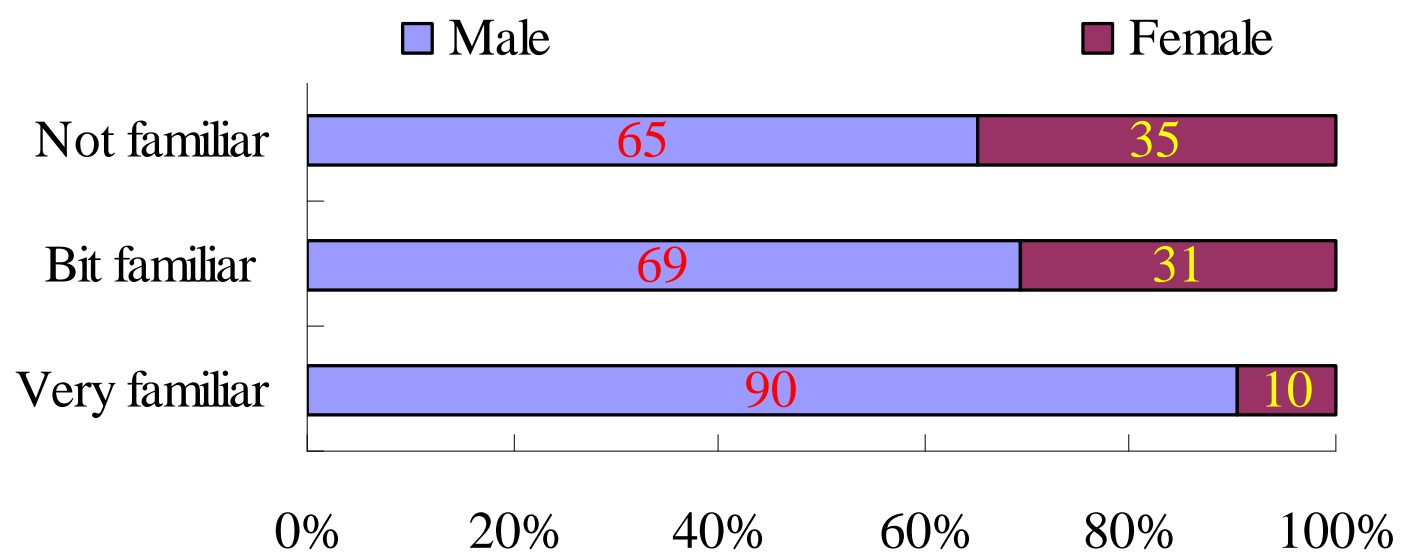

Figure 4 Association between Awareness of UD and Gender $(n=142)$ 


\section{- Gender and Awareness of UD}

Figure 4 depicts the association between awareness of UD and gender. The results show that $90 \%, 69 \%$ and $65 \%$ of men and $10 \%, 31 \%$ and $35 \%$ of women were very familiar, a bit familiar and not familiar with UD, respectively. This indicates that men's level of awareness of UD is higher than that of women. This implies that men are more conscious of the changing society than women.

The survey results show low positive correlation $(r=0.193)$ between the awareness of UD and gender. This hypothesis is significant at a 95\% confidence level. Pearson Chi square $\left(\chi^{2}\right)=6.524$, Degrees of freedom $(\mathrm{df})=2, \mathrm{n}=142$ and $\mathrm{p} \leq 0.05$.

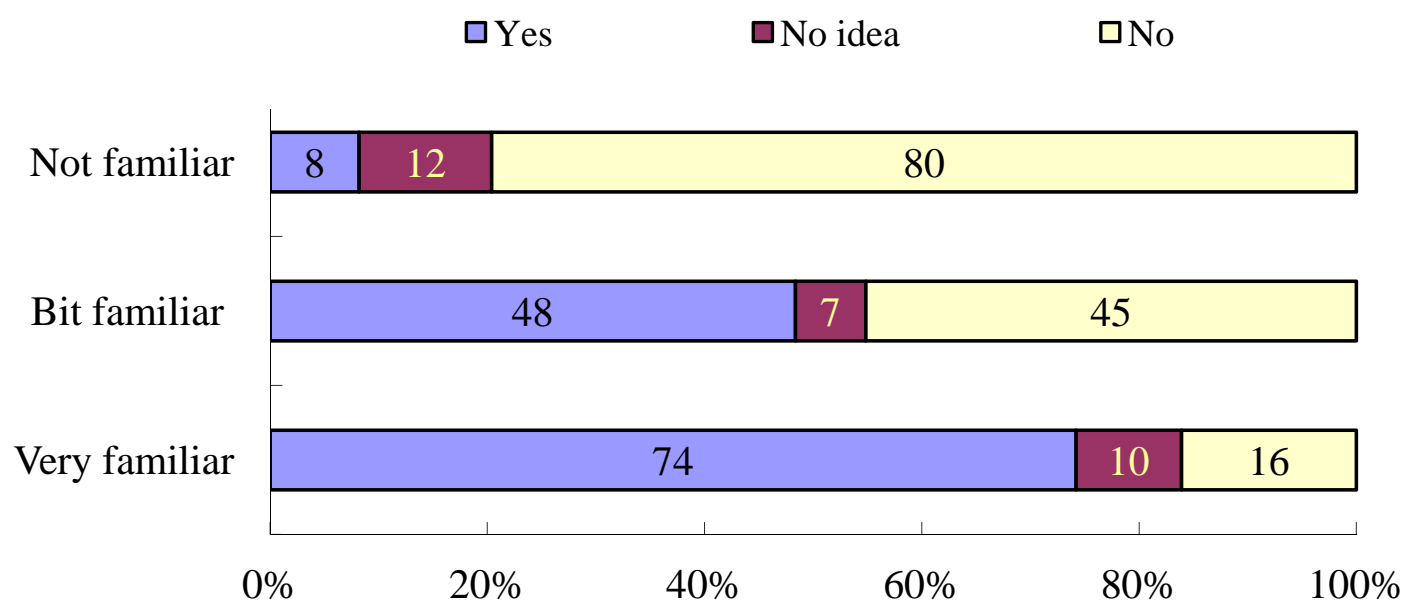

Figure 5 Association between Awareness of UD and Belief that UD is Incorporated in Durable Goods $\quad(n=142)$

\section{- Level of Practices of UD in Durable Goods}

Figure 5 represents the level of current practice of UD in durable goods. It is assumed that awareness of UD affects its practices. Thus, the relationship between awareness of UD and its practices is analyzed. This figure shows that $74 \%$ of respondents who were very familiar with UD and $48 \%$ of respondents who were a bit familiar with UD answered that UD is in practice, whereas $80 \%$ of respondents who were not familiar with UD answered that UD is not in practice. It reveals that respondents who are aware of UD have noticed UD features, whereas those respondents who are not aware of UD have not noticed UD. This also implies that producers are familiar with UD and have been incorporating UD in durable goods despite consumers' lack of familiarity with UD. 
The survey results show that there is a high positive correlation $(r=0.513)$ between the awareness of UD and practice of UD. This hypothesis is significant at a $95 \%$ confidence level. Pearson Chi square $\left(\chi^{2}\right)=39.252$, Degrees of freedom $(\mathrm{df})=4$, $\mathrm{n}=142$ and $\mathrm{p} \leq 0.05$

\section{Present Market of Durable Goods}

This study focuses on five durable goods: rice cookers, television sets, refrigerators, washing machines and air conditioners. This is because these goods are all home appliances and because people are very familiar of these goods.

Figure 6 shows that percentages of respondents who have bought durable goods are higher than those who have not bought durable goods. Durable goods like rice cookers, television sets, and refrigerators are well known among South Asians than washing machines or air conditioners. It reveals that the market for durable goods is high in all South Asian countries. Moreover, a cross tabulation was created to show whether these societies will accept all kinds of durable goods or not. Table 2 shows that the number of respondents who have bought durable goods answered the "societies like durable goods" rather than "societies do not like durable goods." In contrast, some respondents who believe that their societies do not like durable goods have also bought durable goods. It implies that if producers are able to attract consumers through features and convince them about the benefits of UD through advertisement, publicity and exhibition then producers can create market opportunities.

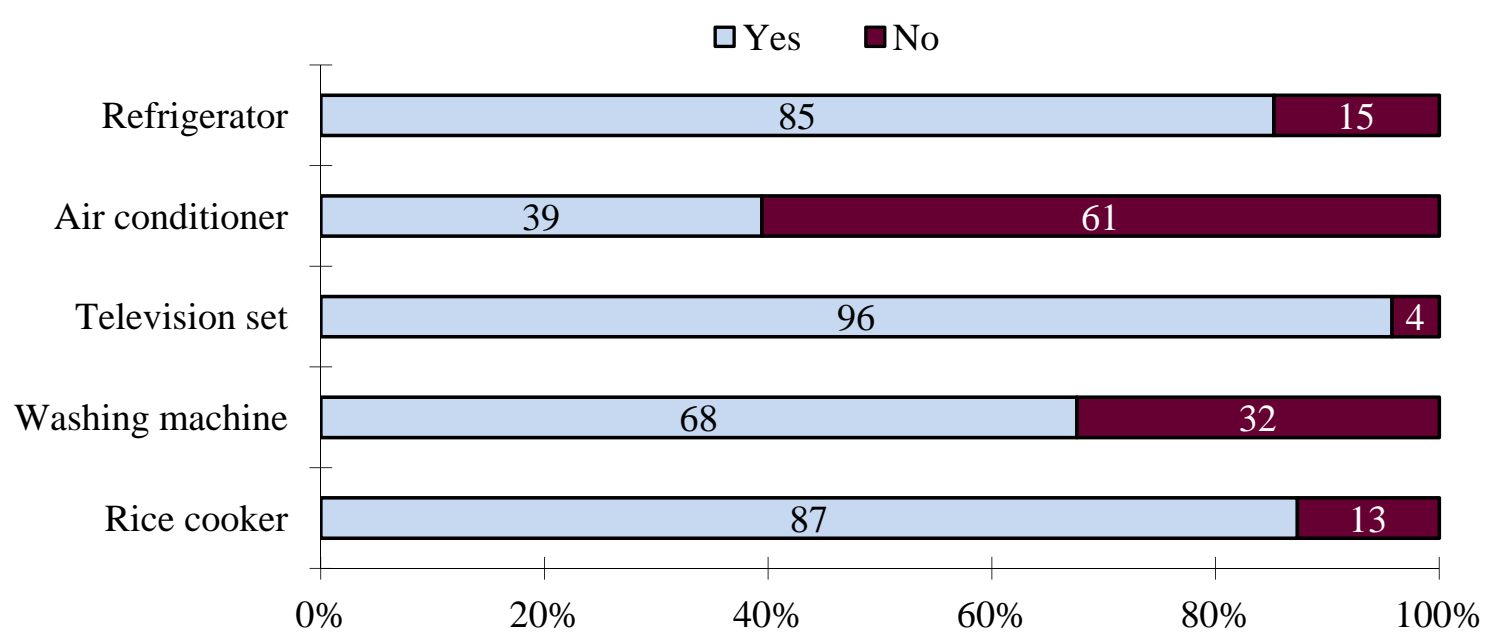

Figure 6 Have Bought Durable Goods $(\mathrm{n}=142)$ 
Table 2 Proportion of Answers to Have Bought Durable Goods by Society Likes to Use Durable Goods $(n=142)$

\begin{tabular}{|c|c|c|c|}
\hline \multirow{2}{*}{ Have bought a } & & \multicolumn{2}{|c|}{ Does your society like to use these products? } \\
\hline & & Yes & No \\
\hline \multirow{2}{*}{ Rice cooker } & Yes & 92 & 8 \\
\hline & No & 72 & 28 \\
\hline \multirow{2}{*}{ Washing machine } & Yes & 88 & 12 \\
\hline & No & 67 & 33 \\
\hline \multirow{2}{*}{ Television set } & Yes & 98 & 2 \\
\hline & No & 100 & 0 \\
\hline \multirow[b]{2}{*}{ Air conditioner } & Yes & 82 & 18 \\
\hline & No & 56 & 44 \\
\hline \multirow{2}{*}{ Refrigerator } & Yes & 98 & 2 \\
\hline & No & 86 & 14 \\
\hline
\end{tabular}

\section{- $\quad$ Product-wise Analysis of the Market}

As durable goods are available in all South Asian countries, the authors try to identify what kinds of products are widely acceptable in which countries. A cross tabulation is created between "does your society like to use these products" and "countries." In the next section, we will explain in brief of three products.

\section{Rice Cookers}

Table 3 and Figure 7 show that South Asian societies like to use rice cookers. Nepal has the highest potentiality for the market of rice cookers, whereas Bangladesh has the lowest. Only 4\% of Nepalese respondents have answered that their society does not like to use rice cookers, whereas $29 \%$ of respondents from Bangladesh believe their society does not like to use rice cookers. This shows that the market for rice cookers is very competitive in all South Asian countries. Thus, it is the right time for producers and designers to incorporate UD features to products to be in the market. Due to the differences of opinions of Nepalese and Bangladeshi respondents, those different strategies are necessary to market rice cookers in each country. 
The survey results show a low positive correlation $(r=0.213)$ between "does your society likes these products," rice cookers and countries. This hypothesis is significant at a $95 \%$ confidence level. Pearson Chi square $\left(\chi^{2}\right)=6.466$, and Degrees of freedom (df) $=1, \mathrm{n}=142$ and $\mathrm{p} \leq 0.05$.

\section{Washing Machines}

Table 3 and Figure 7 show that India has the highest potential for the marketing of washing machines, whereas Bangladesh has the lowest potential. It implies that washing machines are acceptable in all the countries. Some respondents, however, answered that washing machines are not liked by their society. Producers and designers should consider the differences in traditions and religions (Singanpalli, 2001; Prajapati \& Asai, 2009) when incorporating UD into washing machines and when marketing washing machines in Bangladesh and India. One reason for this is because South Asian people wear saris and dhotis, which are 6-9 yards long depending on the region. They are made of silk, cotton or nylon depending on the season, and could catch and tear in the washing machine's small gap between the agitator and the drum (Bhan, 2007).

The survey results show a low positive correlation $(r=0.272)$ between "does your society likes these products," washing machines and "countries." This hypothesis is significant at a 95\% confidence level. Pearson Chi square $\left(\chi^{2}\right)=8.166$, Degrees of freedom $(\mathrm{df})=1, \mathrm{n}=142$ and $\mathrm{p} \leq 0.05$.

\section{Air Conditioners}

Table 3 and Figure 7 show that the market for air conditioners is different from other durable goods. The survey results show the number of respondents who believe that air conditioners are not liked by society is higher than those of other durable goods. Eighty eight percent of Indian respondents answered that their society likes air conditioners. This indicates the presence of market opportunities for air conditioners in India. This is followed by Sri Lankan and Bangladeshi societies (see Table 3 and Figure 7). In contrast, 54\% (the highest) of Nepalese believe that their society does not like air conditioners. It seems that Nepalese society does not like air conditioners because of the following reasons cited by respondents:

(1) The major cities in Nepal have pleasant weather,

(2) The disposable income of most residents of Nepal is not enough to buy air conditioners,

(3) Electricity is periodically (load shedding). 
Table 3 Proportion of Answers Country to Society Likes to Use Durable Goods $(\mathrm{n}=142)$

Does your society like to use these products?

\begin{tabular}{lcccccccccc}
\cline { 2 - 6 } & \multirow{2}{*}{ Rice cooker } & \multicolumn{2}{c}{$\begin{array}{c}\text { Washing } \\
\text { machine }\end{array}$} & \multicolumn{2}{c}{$\begin{array}{c}\text { Air } \\
\text { conditioner }\end{array}$} & $\begin{array}{c}\text { Television } \\
\text { set }\end{array}$ & \multicolumn{2}{c}{ Refrigerator } \\
& Yes & No & Yes & No & Yes & No & Yes & No & Yes & No \\
\hline Bangladesh & 71 & 29 & 67 & 33 & 79 & 21 & 100 & 0 & 100 & 0 \\
India & 88 & 12 & 96 & 4 & 88 & 12 & 96 & 4 & 92 & 8 \\
Nepal & 96 & 4 & 70 & 30 & 46 & 54 & 98 & 2 & 93 & 7 \\
Sri Lanka & 95 & 5 & 95 & 5 & 81 & 19 & 100 & 0 & 100 & 0 \\
Other & 89 & 11 & 94 & 6 & 61 & 39 & 94 & 6 & 100 & 0 \\
\hline
\end{tabular}

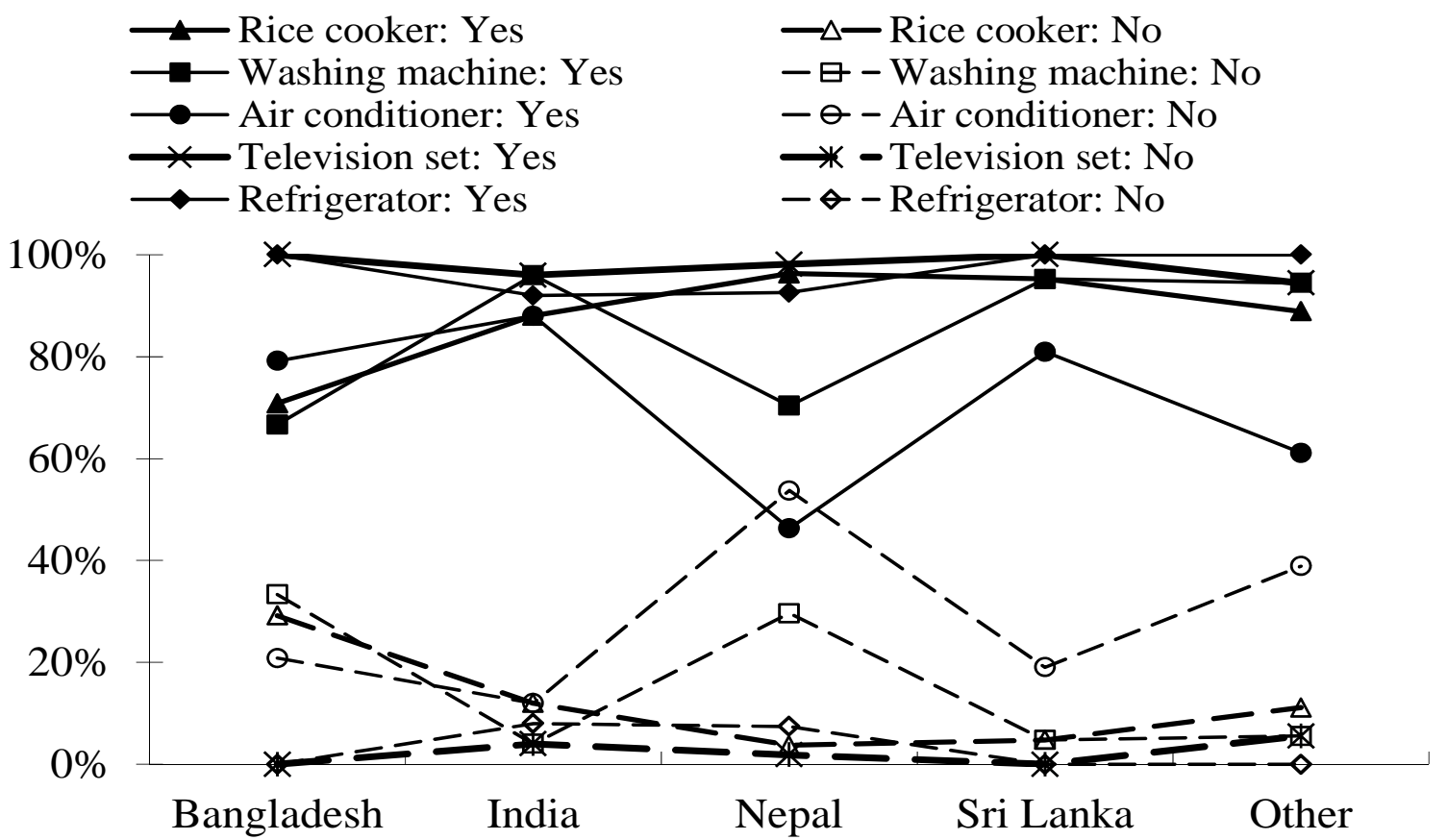

Figure 7 Product-wise Analysis in Various Countries $(n=142)$

Overall the percentage of air conditioners buyers is less than those of other durable goods (see Table 2). It implies that the market for air conditioners is still in its 
initial phase of development. Thus, producers and designers need to create awareness of UD among consumers through advertisements, seminars and exhibitions.

These survey results show low positive correlation $(r=0.272)$ between "does your society like these products”, air conditioners and “countries”. This hypothesis is significant at a 95\% confidence level, Pearson Chi square $\left(\chi^{2}\right)=10.507$, Degrees of freedom $(\mathrm{df})=1, \mathrm{n}=142$ and $\mathrm{p} \leq 0.05$.

Table 4 Proportion of Answers to Have Bought Durable Goods by Main Factor that Is Considered while Buying $(\mathrm{n}=142)$

(Multiple responses converted into $100 \%$ )

(\%)

Main factor that consider while buying

\begin{tabular}{lccccc} 
& & Price & Brand & $\begin{array}{c}\text { Usability and } \\
\text { functionality }\end{array}$ & Attractiveness \\
\cline { 2 - 6 } Have bought a & Yes & 29 & 26 & 30 & 16 \\
\hline \multirow{2}{*}{ Rice cooker } & No & 29 & 26 & 29 & 17 \\
\hline \multirow{2}{*}{ Washing machine } & Yes & 29 & 27 & 29 & 15 \\
& No & 27 & 22 & 32 & 19 \\
\hline \multirow{2}{*}{ Television set } & Yes & 29 & 26 & 29 & 8 \\
\hline \multirow{2}{*}{ Air conditioner } & No & 25 & 25 & 42 & 15 \\
& Yes & 29 & 28 & 28 & 16 \\
\hline \multirow{2}{*}{ Refrigerator } & No & 28 & 24 & 30 & 19 \\
\hline
\end{tabular}

\section{- Most Considerable Factor: Usability and Functionality}

Table 4 is created to find out the factors that respondents consider when buying products. This table shows the percentage of respondents who answered either "Yes" or "No" and those respondents who answered that they consider factors like price, brand, usability and functionality, and attractiveness. The respondents were free to 
choose as many features as they liked. Respondents gave the highest priority to usability and functionality when buying durable goods, but for expensive products such as washing machines and air conditioners they give priority to price. Those respondents who have not bought durable goods also follow the same buying pattern. It reveals that marketing opportunities for UD exist in South Asia because "usability and functionality" is one of the main elements of UD. In addition, respondents indicated that "brand" is given low priority among South Asians.

\section{Needs of UD}

Table 5 and Figure 8 show that $66 \%$ of the respondents face problems while using products even though they do not have any disability at present. The table shows that $16 \%$ of respondents have vision problems and have problems while using products. It is assumed that a problem of one respondent is different from that of other respondents or vision disability may face problems for reasons other than vision impairments problems. The results suggest that both healthy respondents and disabled respondents face problems while using products. Moreover, some disabled respondents have not faced any problems while using durable goods, as they might have only minor disabilities. Similarly, some respondents are unaware of both usability and accessibility of products. They have disabilities, but are uncertain whether they have problems or not. This suggests that market opportunities for UD products exist for both producers and designers.

Table 5 Proportion of Answers to Experienced Problems while Using Durable Goods by Present Disability $(\mathrm{n}=142)$

(Multiple responses converted into $100 \%$ )

\begin{tabular}{|c|c|c|c|c|c|c|c|c|c|}
\hline & & \multicolumn{8}{|c|}{ Present Disabilities } \\
\hline & & $\begin{array}{l}\text { Muscle } \\
\text { strength }\end{array}$ & Vision & Speech & Hearing & Mobility & $\begin{array}{l}\text { Mental/ } \\
\text { Memory }\end{array}$ & Others & None \\
\hline \multirow{3}{*}{$\begin{array}{l}\text { Experienced } \\
\text { problems while } \\
\text { using durable } \\
\text { goods }\end{array}$} & Yes & 0 & 16 & 0 & 0 & 9 & 3 & 6 & 66 \\
\hline & No & 4 & 16 & 1 & 3 & 0 & 3 & 1 & 71 \\
\hline & $\begin{array}{l}\text { Not } \\
\text { sure }\end{array}$ & 7 & 9 & 0 & 0 & 0 & 0 & 2 & 82 \\
\hline
\end{tabular}




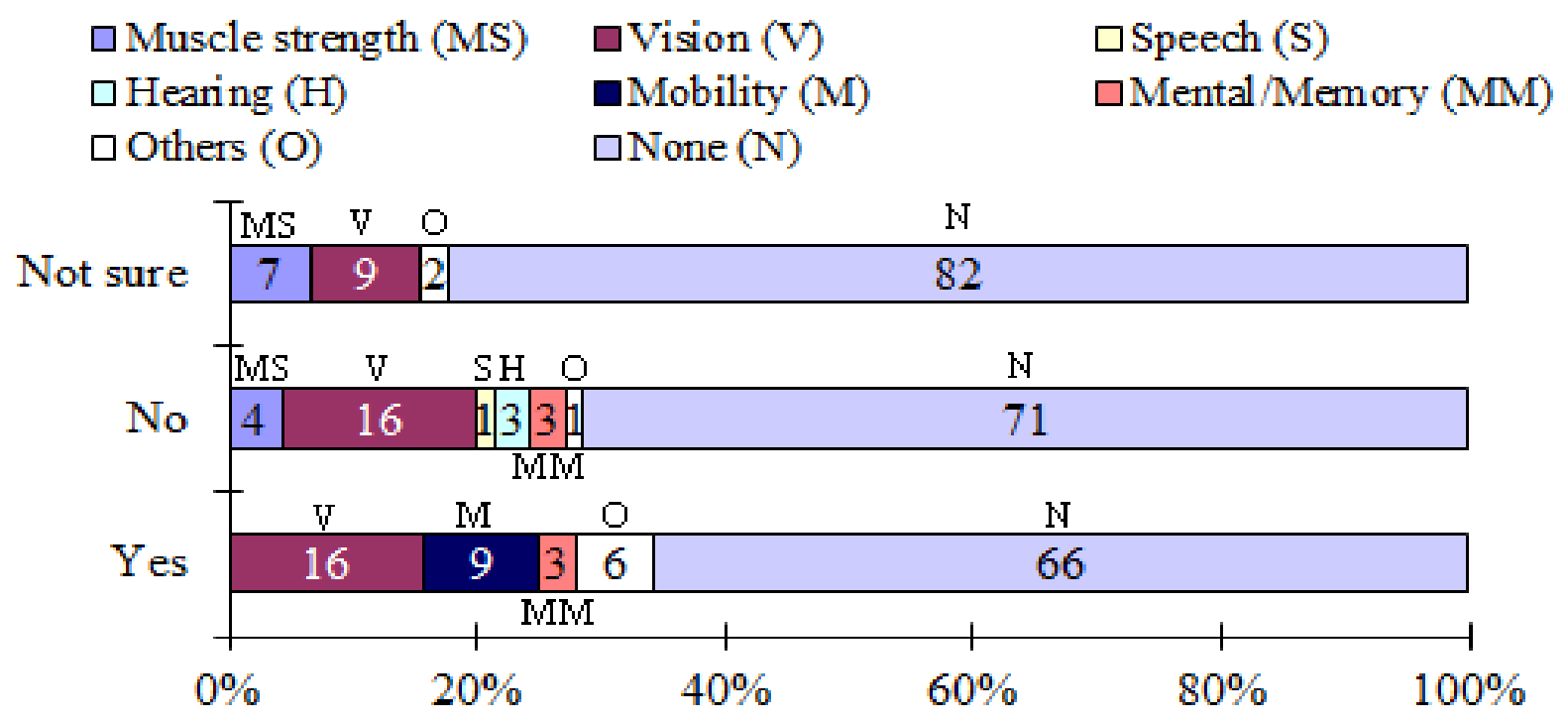

Figure 8 Association between Experienced Problems while Using Durable Goods and Present Disability $(\mathrm{n}=142)$

\section{Most Desired Feature in Products}

In the context of changing customers' expectations, producers and designers face a big challenge of making the right product design. Good design can attract attention of consumers, improve product's performance, cut production costs, and give the product a strong competitive advantage in the market. Features of products play a crucial role for differentiating one's product with competitors' products. Therefore, several questions related to features were designed to find out what consumers like or do not like and the easiest or the safest features.

\section{- Most Liked Feature: Less Energy}

Figure 9 shows that "low consumption of energy like electricity and water, although a bit expensive" is the feature which most respondents are the most concerned about, whereas "energy consuming products, which are cheap" are the least concerned. It implies that producers and designers should give high priority to less energy consuming products over energy consuming products. 


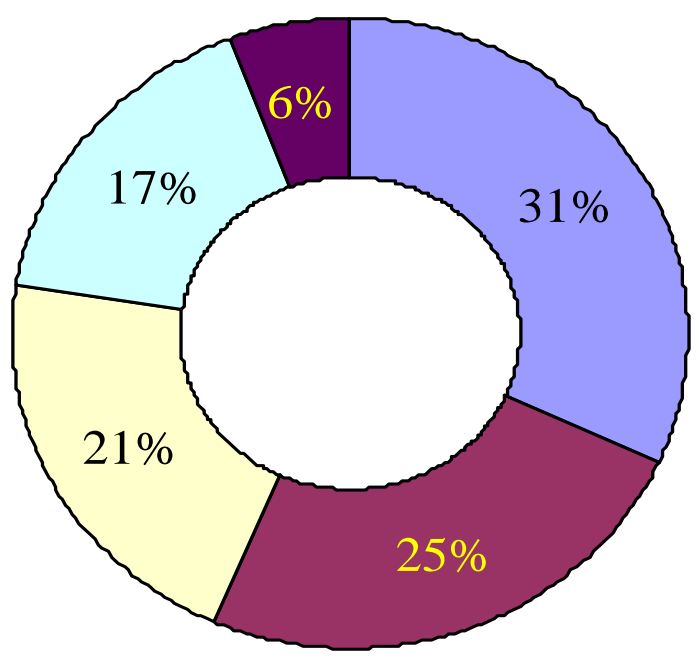

Less energy consuming but a bit expensive

$\square$ A bit expensive but comfortable to use

$\square$ High speed

Silent in operation

Energy consuming and cheap

Figure 9 Percentages of Liked Features $(n=142)$

\section{- Do Not Like Feature: Huge Size}

Figure 10 shows that $52 \%$ of respondents do not like "huge sized" products. The two features "expensive" and "multi-functional" follow this. It implies that consumers are conscious about independent living so that they can buy and use those products without others help.

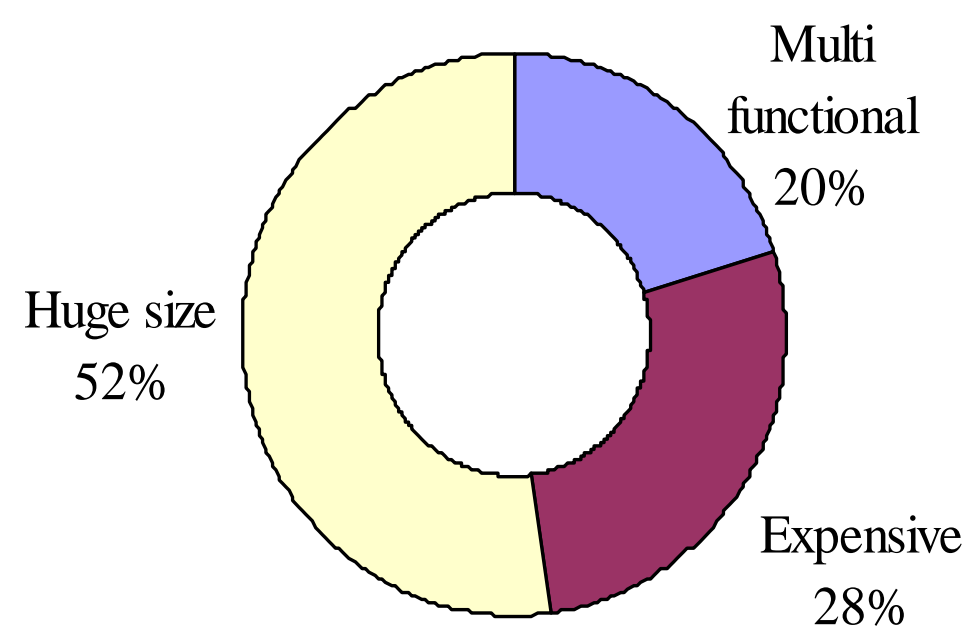

Figure 10 Percentages of Do Not Like Features $(n=142)$ 


\section{- Most Preferred Feature of Usability: Easy to Use}

Figure 11 shows that $43 \%$ of respondents like "easy to use" feature in products than those of other features, whereas "stylish exterior design" is the least preferred feature among all. It implies that producers and designers can innovate many features according to the market, but their primary concern should be ease of use of products.

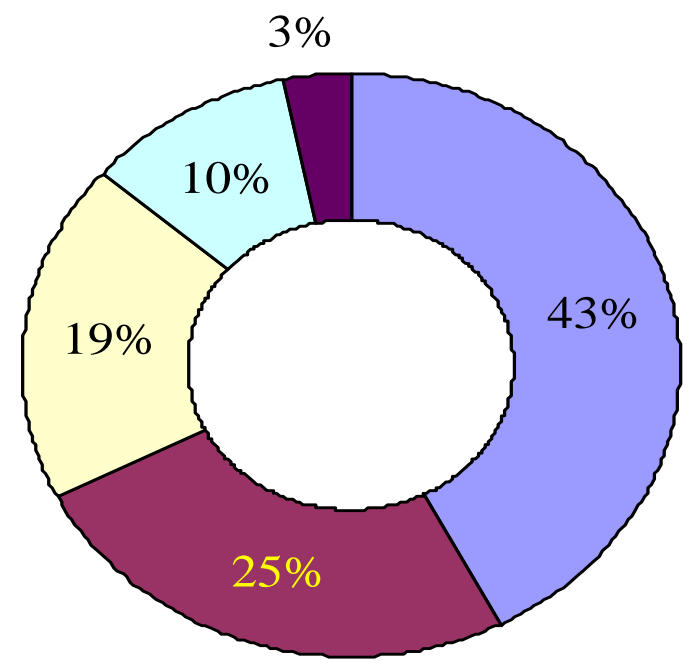

Easy to use

$\square$ Few buttons

$\square$ Large letters and big buttons

Good contrast

$\square$ Stylish exterior

Figure11 Percentages of Preferred Easier Features $(n=142)$

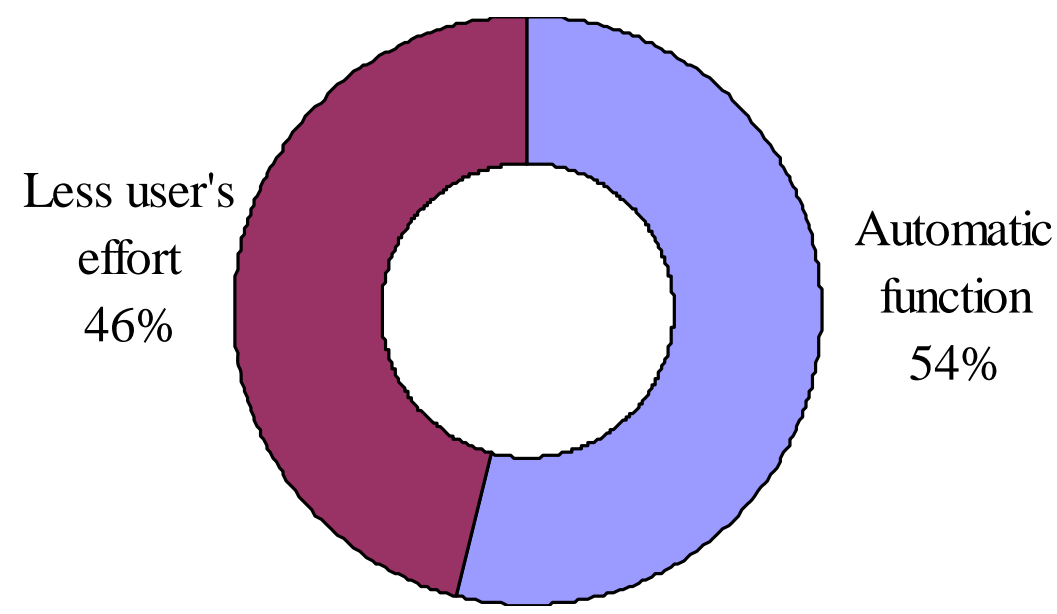

Figure 12 Percentages of Preferred Safer Features $(n=142)$

\section{- Most Preferred Feature of Safety: Automatic Function}

Figure 12 shows that automatic function is the most preferred feature concerning the safety of consumers. This indicates that consumers want to be relieved when they 
run a machine. This implies that consumers like to use those products, which require reasonable operating forces and minimum repetitive actions.

\section{Attitudes of Various Age Groups toward Features}

\section{- Most Liked Feature}

A cross tabulation (see Table 6) is created to study the most preferred feature among various age groups. Table 6 shows that both age groups between 20-39 and 40-59 like "less energy consuming products, but a bit expensive" than those in other age group 60 or over. The age group of 60 or over, however, likes "a bit expensive, but comfortable to use products". It implies that the young are more concerned about environmental issues, whereas the aged are concerned about their health. Thus, if producers and designers like to target the aged, they are recommended to produce comfortable to use products.

Table 6 Proportion of Answers to Age Group by Preferred Features of the Products

$$
(\mathrm{n}=142)
$$

\begin{tabular}{l|c|c|c|c|c}
\multicolumn{7}{c}{ (Multiple responses converted into $100 \%)$} & (\%) \\
\hline Age group & $\begin{array}{c}(1) \\
\text { High speed }\end{array}$ & $\begin{array}{c}(2) \\
\text { Less energy }\end{array}$ & $\begin{array}{c}\text { (3) } \\
\text { Silent in } \\
\text { operation }\end{array}$ & $\begin{array}{c}(4) \\
\text { Energy } \\
\text { consuming }\end{array}$ & $\begin{array}{c}\text { (5) } \\
\text { Comfortable to } \\
\text { use }\end{array}$ \\
\hline 20-39 & 19 & 33 & 17 & 7 & 24 \\
$40-59$ & 27 & 31 & 15 & 4 & 23 \\
60 or over & 18 & 27 & 15 & 3 & 36 \\
\hline
\end{tabular}

Note: (1) High speed, (2) Less energy consuming, but a bit expensive, (3) Silent in operation, (4) Energy consuming and cheap, (5) A bit expensive, but comfortable to use

\section{- Preferred Feature of Usability by Various Age Groups}

Table 7 is created to know the most preferred features of usability for different age groups. Interestingly, it shows that all the respondents like or prefer "easy to use" products rather than those of other features. On the contrary, "stylish exterior design" is the least preferred feature by the two different age groups 20-39 and 60 or over. The age group 40-59 gives the least preference to "good contrast". It reveals that the preferred feature of usability is different with age groups. It may be due to their income. 
Table 7 Proportion of Answers to Age Group by Preferred Easiest Feature of Products (while operating) $(n=142)$

(Multiple responses converted into $100 \%$ )

(\%)

\begin{tabular}{lccccc}
\hline \multirow{2}{*}{ Age group } & $\begin{array}{c}(1) \\
\text { Large letters }\end{array}$ & $\begin{array}{c}(2) \\
\text { Few buttons }\end{array}$ & $\begin{array}{c}(3) \\
\text { Good contrast }\end{array}$ & $\begin{array}{c}(4) \\
\text { Easy to use }\end{array}$ & \begin{tabular}{c} 
Stylish exterior \\
\hline $20-39$
\end{tabular} \\
21 & 25 & 11 & 41 & 1 \\
$40-59$ & 16 & 25 & 7 & 44 & 8 \\
60 or over & 16 & 25 & 13 & 44 & 3 \\
\hline
\end{tabular}

Note: (1) Large letters and big buttons, (2) Few buttons, (3) Good contrast, (4) Easy to use, (5) Stylish exterior

\section{- Preferred Feature of Safety}

Table 8 is created to know the most preferable features for safer use of products. Surprisingly, all age groups prefer “automatic function” to “less user's effort”. It implies that for safe running of products automatic function is better than some manual function, even if it can be performed through the less effort.

Table 8 Proportion of Answers to Age Group by Preferred Safest Features of Products (while operating) $(\mathrm{n}=142)$

(Multiple responses converted into $100 \%) \quad$ (\%)
Age group
(1) Automatic function
(2) Less user's effort

\begin{tabular}{lll}
\hline $20-39$ & 55 & 45 \\
$40-59$ & 51 & 49 \\
60 or over & 56 & 44 \\
\hline
\end{tabular}

Note: (1) Automatic function (from start to end), (2) Less user's effort required

\section{Business Opportunities of UD in South Asia}

\section{- Probability of Market Expansion}

Figure 13 is created to know whether the awareness of UD makes any difference in consumers' opinion about the market of UD products. Figure 13 shows that $58 \%$ of respondents who were very familiar with UD and $47 \%$ of respondents who were a bit familiar with UD answered that incorporation of UD in products will increase the 
market opportunity. Similarly, 37\% of respondents who were not familiar with UD also believed that the market "May" increase.

Meanwhile, the most likely explanation for this finding is that the percentage of respondents who believe that UD will increase the market of durable goods is higher than those respondents who believe "No" or market will not increase. There are high probabilities of increment in the market because the more respondents who are very familiar with UD believe that it will increase the market of products, the more probabilities that it will occur.

The survey result shows moderate positive correlation $(r=0.346)$ between the awareness of UD and belief that demand of UD incorporated products will increase. This hypothesis is significant at a 95\% confidence level. Pearson Chi square $\left(\chi^{2}\right)=$ 21.406, Degrees of freedom $(\mathrm{df})=6, \mathrm{n}=142$ and $\mathrm{p} \leq 0.05$.

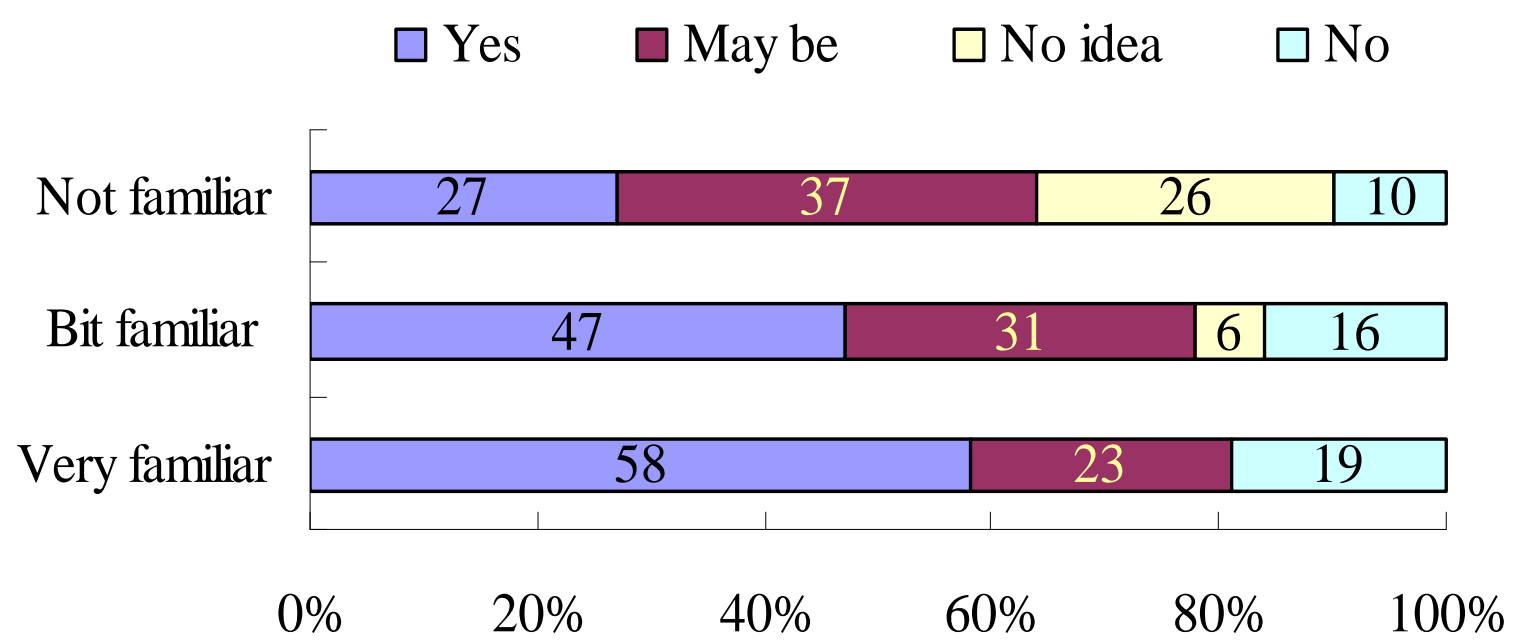

Figure 13 Association between Awareness of UD and Belief that the Market of UD Products Will Increase $(\mathrm{n}=142)$

\section{- Willingness to Pay for UD Products}

Figure 14 is created to illustrate respondents' willingness to pay for UD products and to suggest which country's respondents would be willing to pay more for UD products. Figure 13 shows that all of the respondents were willing to pay $10 \%$ more than the current price of ordinary products. Forty percent of respondents were willing to pay $25 \%$ more. Similarly, about $8 \%$ of respondents were ready to pay $50 \%$ more and $3 \%$ of respondents were ready to pay $100 \%$ more than the current price of ordinary products. 


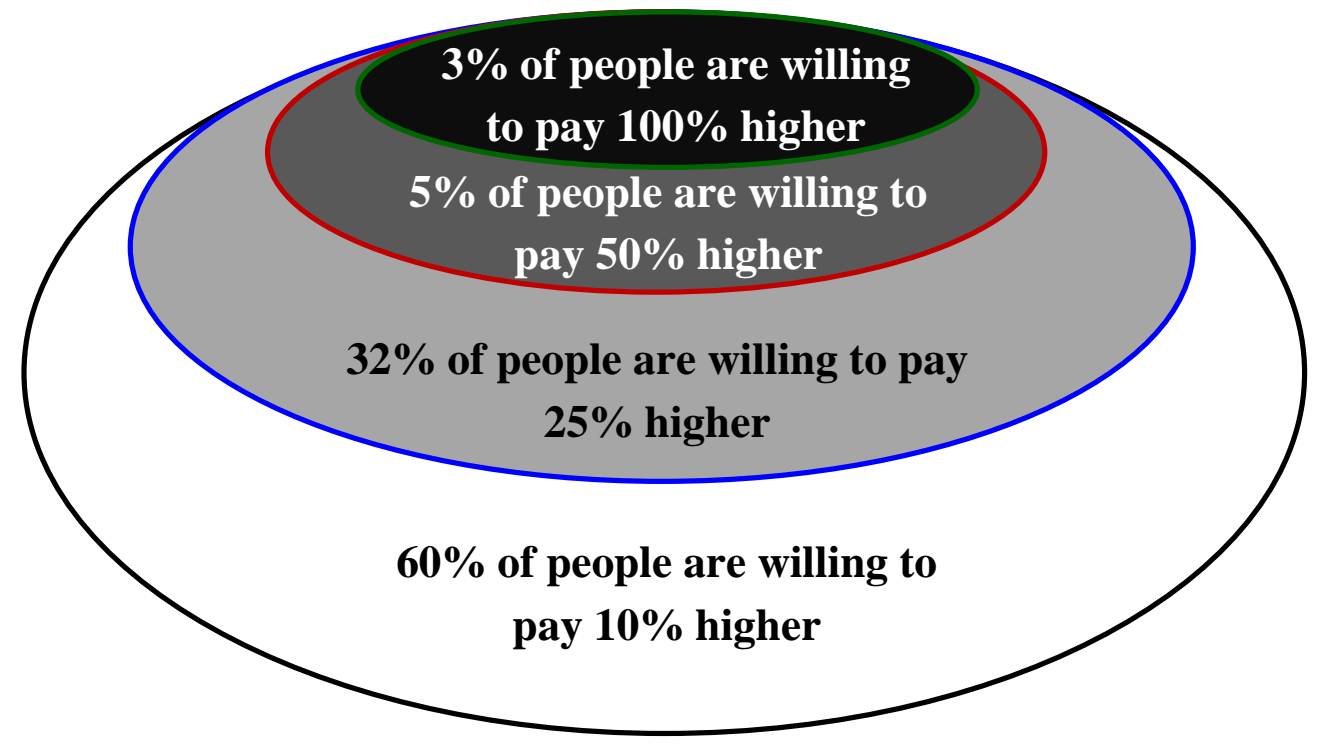

Figure 14 People’s Willingness to Pay for UD Products $(n=142)$

Figure 15 shows that $83 \%, 64 \%$ and $71 \%$ of respondents from Bangladesh, India and Sri Lanka, respectively, were willing to pay $10 \%$ more than the current price of ordinary products for UD products. The percentage of respondents who were willing to pay a price greater than $25 \%$ above the current price was lower than those of respondents who were willing to pay $10 \%$ in Bangladesh, India and Sri Lanka. In contrast, $48 \%$ of Nepalese respondents reported that they were willing to pay up to $10 \%$ more and 52\% were willing to pay $25 \%$ more for UD products. Furthermore, some Nepalese respondents were willing to pay even $50 \%$ or $100 \%$ more for UD products.

It implies that UD products are accepted easily in South Asia even if the price is increased by over $25 \%$ of ordinary products. If the price of UD products, however, rises higher than $25 \%$ of ordinary products then only a few consumers will buy it. The reason behind this is their rising disposable income (see Table 9). UD motivates South Asians to buy durable goods. Residents of South Asian countries cannot, however, buy same products repeatedly because the income level is still lower than that of developed countries.

The survey results show low positive correlation $(r=0.214$. $)$ between the willingness to pay for UD and country. This hypothesis is significant at a 95\% confidence level. Pearson Chi square $\left(\chi^{2}\right)=26.117$, Degrees of freedom $(\mathrm{df})=12$, $\mathrm{n}=142$ and $\mathrm{p} \leq 0.05$. 
Table 9 GDP of Four South Asian Countries

\begin{tabular}{|c|c|c|c|c|c|}
\hline \multirow{2}{*}{ No. } & \multirow{2}{*}{$\begin{array}{c}\text { World } \\
\text { ranking } \\
(2009)\end{array}$} & \multirow{2}{*}{ Country } & \multicolumn{2}{|c|}{ GDP per capita in U.S. \$ } & \multirow{2}{*}{$\begin{array}{c}\text { Increase in GDP per capita } \\
\text { in U.S. \$ (in } 5 \text { years) }\end{array}$} \\
\hline & & & 2004 & 2009 & \\
\hline 1 & 158 & Bangladesh & 392 & 559 & 167 \\
\hline 2 & 144 & India & 599 & 1,033 & 434 \\
\hline 3 & 168 & Nepal & 274 & 471 & 197 \\
\hline 4 & 121 & Sri Lanka & 1,063 & 2,041 & 979 \\
\hline
\end{tabular}

Source: International Monetary Fund, 2009

$10 \%$ higher

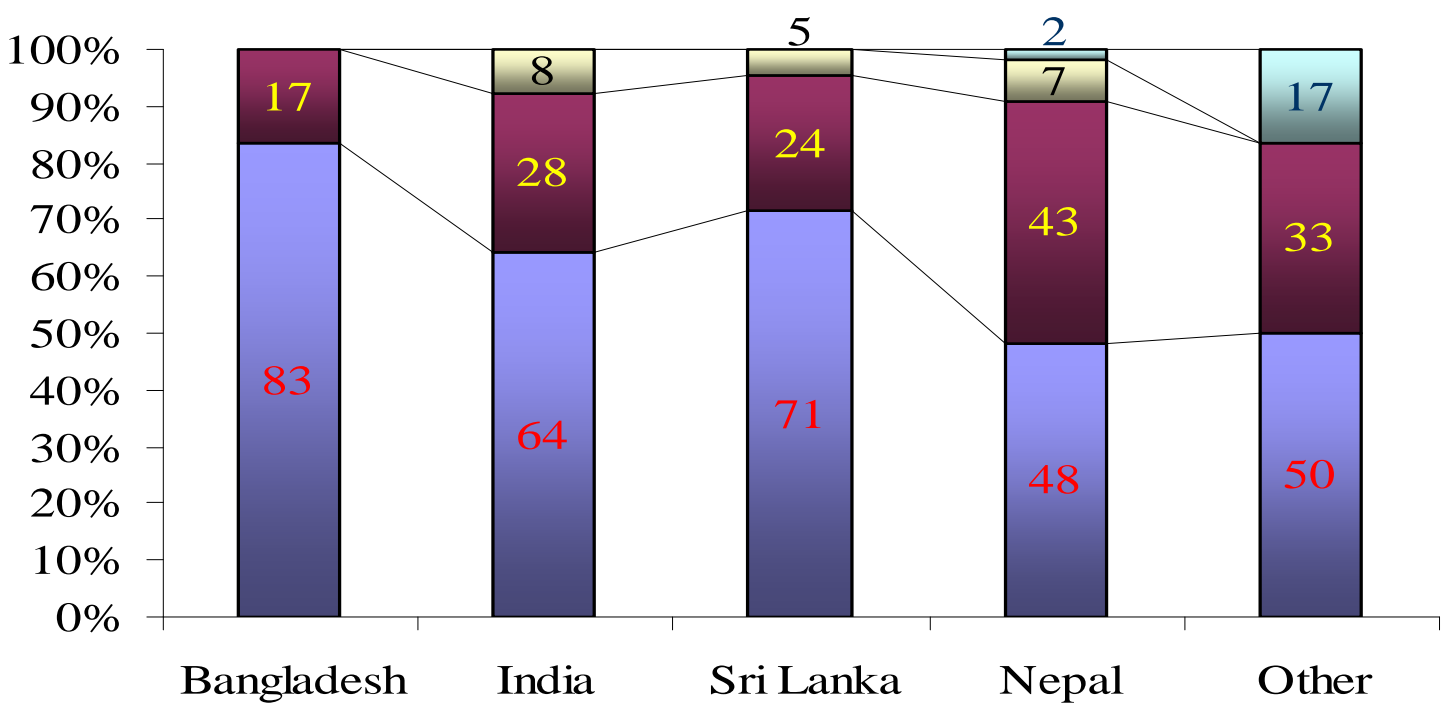

Figure 15 Willingness for UD Products Country-wise $(\mathrm{n}=142)$

\section{RECOMMENDATIONS FOR PRODUCERS AND DESIGNERS}

One of the purposes of this research is to recommend areas that producers and designers should consider when incorporating UD in products. The recommendations are as follows:

1. Traditions and religions should be considered when incorporating UD so that design is not rejected outright.

2. The aged, the disabled and children should be involved in awareness activities like advertisements to attract the attention of those groups. 
3. Products should be designed well so that consumers do not need to make adjustments to compensate for the shortcomings of features.

4. Producers and designers should try to reduce the percentage of consumers who face problems while using products. They should attempt to gain a thorough understanding of consumers' problems, create innovative features to solve the major problems, and emphasize features that consumers like while trying to minimize or eliminate those consumers do not like.

\section{CONCLUSIONS}

This paper was an effort to identify the current rate of awareness of UD and its practices in durable goods in South Asia The hypotheses are developed to address the research questions and tested using data collected from respondents. From this survey, the following conclusions can be drawn.

1. "UD” is not well known in South Asia. The most familiar term is "design for all," This shows that even though South Asians are not aware of UD, they practice UD in different terminology.

2. The level of awareness of UD among men is higher than that among women. This fact implies that companies who market UD should direct more of their efforts toward women.

3. It has been proven that producers and designers are aware of UD although consumers are not very familiar with UD.

4. It has been proven that South Asians like durable goods. There will be more business opportunities if producers and designers focus on usability and functionality of durable goods.

5. Producers and designers should try to find the most appropriate strategy for each type of UD products. For example, the marketing of rice cookers needs to be adjusted to meet the different needs of residents in Nepal and Bangladesh, which have different belief systems. Washing machines must be designed according to the cultural traditions and religions of the target audiences. Air conditioner marketing is still in its initial phase of development, and advertisements, seminars and exhibitions would help raise awareness among consumers of air conditioners and their features.

6. Producers and designers should focus on UD features like "easy to use" and "automatic functions." The production of "huge size products" and "energy consuming products" should be minimized because consumers in South Asia do not prefer such products. 
7. Attitudes of various age groups toward features are different, but UD features enable people of all age groups to be more independent than ordinary features do.

8. South Asians will buy UD products even if their prices increase up to $25 \%$ higher than those of ordinary products. Only a few consumers will, however, buy if it is more expensive than $25 \%$ above the usual price.

9. Both the disabled and the healthy face problems in using ordinary products. The need for UD products motivates consumers to buy UD products. Therefore, UD products have high business potential in South Asia.

This paper has several limitations. First, the survey was carried out in four major countries of South Asia. The findings here should not be generalized to include the other South Asian countries (Afghanistan, Bhutan, Maldives, and Pakistan). Second, the number of respondents from rural areas is small. A comparative study between urban and rural cannot be examined. Finally, only literate respondents are considered. To extract actual comprehensive information, people from different education levels and occupations should also be taken into account. Nevertheless, even with these limitations, this study has successfully achieved its aims and has opened new avenues for future work. To eliminate the limitations mentioned above, another survey should be carried out to cover all South Asian countries. In addition, people from rural areas and people from various occupations should be included. Another potential pursuit is a comparative study of South Asia and Japan to explore the gap between Japan and South Asia concerning the awareness of UD and identify possible solutions to fill the gap. This paper represents the first attempt to assess the level of awareness of UD products in South Asia.

\section{REFERENCES}

Asai, T. \& Konta, Y. (2006). Development of Simple Measures of UD and their Application to Evaluation of Corporate Management. Journal of Japan Association for Management Systems, 23(1), 53-60.

Agarwal, A. \& Anand, M. C. (2007). Creating "Non-handicapping Physical Environments" for persons with reduced mobility and disabilities. Basin -

South Asia (No. 8, pp. 2). http://www.rollingrains.com/archives/

Newsletter_No\%5B1\%5D._8.pdf

Ashok, M. \& Jacko, J.A. (2009). Dimensions of User Diversity. In Stephanidis C. (Ed.), The Universal Access Handbook (pp. 4.1-14.15). Boca Raton, FL: CRS Press. http://dx.doi.org/10.1201/9781420064995-c4 
Benktzon, M. (1993). Designing for Our Future Selves: the Swedish Experience. Applied Ergonomics, 24(1), 19-27. http://dx.doi.org/10.1016/0003-6870(93)90155-3

Bhan, N. (2007). The world Washer Whirlpool Enters the Indian Market. Retrieved from http://nitibhan.typepad.com/Niti_Bhan_Whirlpool.doc Elokla, N., Morita, Y. \& Hirai, Y. (2006). Understanding of the Concept of Universal Design Among Overseas and Japanese Institutions and Manufactures. Proceedings of International Symposium Universal Design and Visitability: From Accessibility to Zoning. Columbus, USA: The Ohio State University.

Erlandson, R. F. (2008). Universal and Accessible Design for Products, Services, and Processes (pp. 288). Boca Raton, FL: CRS Press. http://dx.doi.org/10.1201/9781420007664

Goldsmith, S. (2001). The Bottom-up Methodology of Universal Design. In W.F.E.

Preiser \& E. Ostroff (Eds). Universal Design Handbook (pp. 25.1-25.16). New York, NY: McGraw-Hill.

Hasegawa, M. \& Asai, T. (2007). The Effect of Universal Design Level in Management of Enterprise Value. Journal of Japan Association for Management Systems, 24(1), 67-72.

Ikeda, K. (2005). Trends Toward Universal Design in Japan. Fujitsu Science and Technical Journal, 41(1), 31-37. http://www.fujitsu.com/downloads/ MAG/vol41-1/paper05.pdf

International Monetary Fund (2009). World Economic Output Database, October 2009. Retrieved from http:/www.imf.org/external/pubs/ft/weo/2009/02/weodata/index.aspx Keates, S., Clarkson, P., Harrison, L. \& Robinson, P. (2000). Towards a practical inclusive design approach. Proceedings of the $1^{\text {st }}$ ACM Conference on

Universal Usability (pp. 45-52). Arlington, VA: Association for Computing Machinery (ACM).

Mace, R. (2008, October 19). About UD [The Center for Universal Design].

Retrieved from http://www.design.ncsu.edu/cud/about_ud/about_ud.htm

Pauls, J. (2001). Life Safety Standards and Guidelines focused on Stairways. In W.F.E. Preiser \& E. Ostroff (Eds.), Universal Design Handbook (pp. 23.1-23.19). New York, NY: McGraw-Hill.

Prajapati, N. \& Asai, T. (2009). Implementation of universal design and its opportunities in Indian Market. The 10th South Asian Management Forum, Change and Continuity: management Prospects and Challenges (pp. 171-178). Thimphu, Bhutan: Association of Management Development Institutions in South Asia (AMDISA). 
Prajapati, N. \& Asai, T. (2010), A Comparative Study of Universal Design in South Asia and Japan, The 3rd International Conference for Universal Design in Hamamatsu (CD - ROM: 10p) Hamamatsu, Japan: International Association for Universal Design (IAUD).

Prajapati, N. \& Asai, T. (2010). Marketability of Universal Design (UD) Products in India: The Case of Panasonic and a UD Proposal for Washing Machines. South Asian Journal of Management, 17(4), 134-156.

Raheja, G. (2007). Universal Design: An Integrated Approach. Retrieved from http://www.accessability.co.in/access/articles/Universal-Design

Singanapalli, B. (2001). Universal Design and the Majority World. In W.F.E. Preiser \& E. Ostroff (Eds.), Universal Design Handbook ～(pp. 5.1-5.20). New York, NY: McGraw-Hill.

Steinfeld, E. \& Shea, S. (2001). Fair Housing: Toward Universal Design in MultiFamily Housing. In W.F.E. Preiser \& E. Ostroff (Eds.),

Universal Design Handbook (pp. 35.1-35.13). New York, NY: McGraw-Hill.

United Nation, Department of Economic and Social Affairs (2008). World Population Prospects: The 2008 Revision Population Database.

Retrieved from http://esa.un.org/unpp/index.asp?panel=2.

Wijk, M. (2001). The Dutch Struggle for Accessibility Awareness.

In W.F.E. Preiser \& E. Ostroff (Eds.), Universal Design Handbook (pp. 28.1-28.17). New York, NY: McGraw-Hill.

Yoshida, H. and Asai, T. (2009). Influence of Universal Design on Corporate Value in Electric Industry. The $42^{\text {nd }}$ National Conference of Japan Association for Management Systems, (pp.184-185). Tokyo, Japan: Japan Association for Management Systems (JAMS). 
